\title{
DOI: http://dx.doi.org/10.20535/0203-3771382019184100
}

Д. І. Хенченко ${ }^{1}$, технолог, О. П. Мариношенко ${ }^{2}$, к. м.н., дочент,

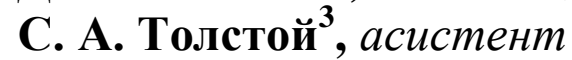

\section{СИСТЕМА ДОЗАПРАВКИ У ПОВІТРІ ЯК ШЛЯХ ДО АВТОНОМНОСТІ ВІЙСЬКОВО-ТРАНСПОРТНОЇ АВІАЦІї}

The need for the aircraft autonomy of military transport aviation of Ukraine was considered. An analysis of the existing structures was carried out and an adaptive model for the installation of air refueling systems on the «An» aircraft of the Ukrainian army, which are already in operation and those that will be produced in the basic version, was proposed. The prospects for the re-equipment of aircraft with the most positive impact on production were substantiated.

Рассмотрена необходимость автономности работы самолетов военнотранспортной авиации Украины. Выполнен анализ существующих конструкций и предложена адаптивная модель установки систем дозаправки в воздухе на самолетах «Ан» украинской армии, которые уже эксплуатируются и тех, которые будут выпускаться в базовом варианте. Обоснованы перспективы переоснащения самолетов с наиболее позитивным влиянием на производство.

\section{Вступ}

Сучасна геополітична ситуація, що склалася в Україні, а саме, проведення АТО на сході України і проблематика тимчасово окупованих Російською Федерацією Криму і окремих районів Донецької і Луганської областей, призвела до необхідності глибокої модернізації армії, зокрема, військово-повітряних сил (ВПС). Хронічний дефіцит коштів, призупинення або «заморожування» робіт із виробництва та ремонту літальних апаратів (ЛА) на цілому ряді підприємств поставило питання щодо не створення, а модернізації існуючих одиниць техніки.

Успішні роботи із модернізації ЛА, силами вітчизняних підприємств і організацій, могли би стати тою відправною точкою для створення сучасних ЛА, у конструкції яких були б враховані позитивні зміни, які стали наслідками такої модернізації. Так, наразі в українській армії, у якості літаків військово-транспортної авіації, використовуються: Ан-26, Ан-30, Ан-70 (у єдиному екземплярі), Ил-76. У перспективі, згідно із відкритою інформаці$\epsilon ю$ із цього питання $[1,2]$, цей парк може бути поповнений літаками Ан-32, Ан-132, Ан-148 (спеціального призначення), Ан-178.

\footnotetext{
${ }^{1}$ ДП "Антонов"

${ }^{2}$ КПІ ім. Ігоря Сікорського

${ }^{3}$ КПІ ім. Ігоря Сікорського
} 
Широкий спектр задач, що виконують армійські літаки, передбачає досить високі вимоги до тривалості знаходження у повітрі, без можливості періодичної посадки на аеродроми базування для дозаправки паливом. Це, у свою чергу, веде до необхідності наявності на борту систем дозаправки у повітрі (СДуП), якою не обладнаний жодний із зазначених вище літаків ВПС України. Кінець війни настане, а українській армії бути і потім. I мати у своєму складі сучасні ЛА, що можуть годинами баражувати на кордонах для несення служби у якості розвідників, або перевозити гуманітарну допомогу у віддалені райони, маючи можливість автономної роботи протягом тривалого часу. Саме тому встановлення СДуП на літаках військовотранспортної авіації є актуальним предметом для обговорення.

\section{Постановка задачі}

Тривалість польоту літака передусім залежить від його аеродинамічних характеристик та кількості палива на борту. Враховуючи, що остання безпосередньо пов'язана із максимальною злітною вагою ЛА та не може зростати нескінченно, бо призведе до зменшення питомої ваги спеціального обладнання та (або) екіпажу, стає необхідним наявність у літаку СДуП. Слід зазначити, що проблематика встановлення таких систем на літаках Української армії може стосуватися лише ЛА марки «Антонов», адже стосовно Ил-76 такі зміни можуть здійснюватися лише за погодженням із розробником, що зі зрозумілих причин не може бути виконаним.

Отже, що стосується літаків «Ан», то найближчими конкурентами їх є європейський Airbus A400M (для Ан-70) і бразильський Embraer KC-390 (для Ан-178). Постачання серійних машин вказаних моделей у відповідні армії світу є вирішеною проблемою, адже вони вже обладнані СДуП у базовому варіанті конструкції (рис. 1).

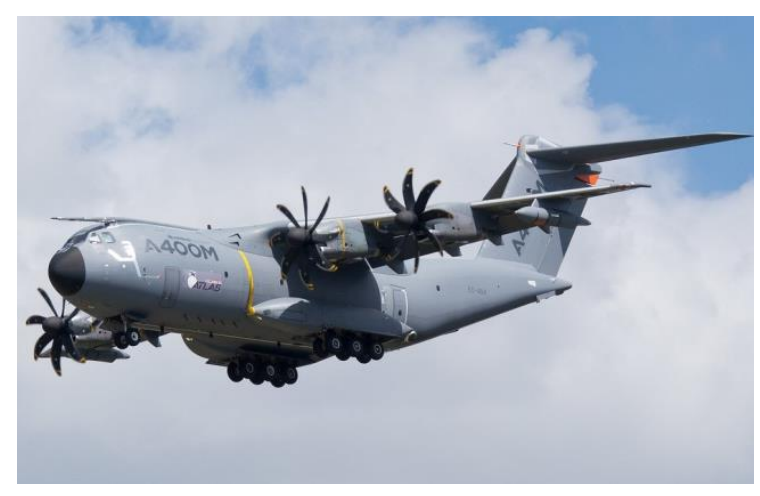

a)

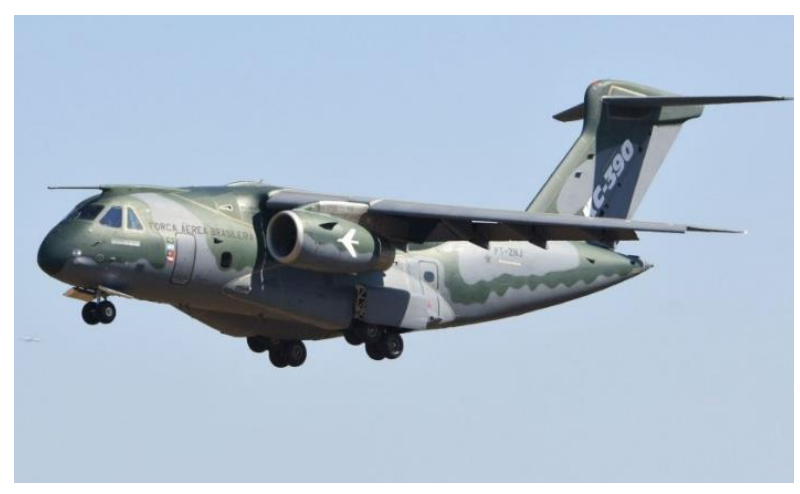

б)

Рис. 1. Літаки, обладнані СДуП: $a$ - Airbus A400M; $\sigma$ - KC-390

Вимоги компаній-замовників щодо наявності СДуП на борту задоволені вже на етапі розробки, а не вимушеної модернізації. Пропозиція щодо 
модернізації літаків «Ан», які знаходяться на озброєнні, у цьому контексті $\epsilon$ тим більше актуальною.

Відсутність відповідного досвіду у розробці, виготовленні та монтажу СДуП на вітчизняних літаках, із першого погляду, передбачає залучення фахівців 3-за кордону для проведення таких робіт. Згаданий вище брак коштів повністю суперечить такому рішенню, а тому представляється очевидним відкриття в Україні власної школи проектування та встановлення СДуП на літаках. У разі прийняття позитивного рішення цього питання, власне, на рівні керівництва країни, можна розширити діапазон задач для такої школи, пов'язаних із розробкою ще і літаків-танкерів. Останні також, зрозуміло, не використовуються в Україні, але можуть з'явитися як модернізовані літаки, зокрема, на базі Ан-26 (для дозаправки літака Ан-32) i Ан-124 (для літаків Ан-70, Ан-178).

\section{Огляд можливих СДуП для встановлення на літаки «Ан»}

На сьогоднішній день існує три види СДуП, які відрізняються комплектом спеціального обладнання для виконання дозаправки. Так, у якості такого комплекту використовуються:

- троси і гнучкий шланг;

- жорстка телескопічна труба;

- гнучкий шланг і конус.

СДуП із використанням тросів і гнучкого шлангу була вперше запропонована у 1917 р. в Росії, а запатентована у США у 1921 р. російським інженером-емігрантом О. Сєвєрським. Через два роки вперше у історії була виконана така операція між літаками Airco DH.4 (рис. 2).

Така СДуП (із використанням тросів і гнучкого шлангу) передбачає наявність на кінці шлангу заправного пістолета, який повинен бути «спійманий» літаком, що потребує дозаправки, а це є небезпечною і досить нестабільною процедурою, яка висуває досить високі вимоги по обмеженню швидкості польоту і стану атмосфери в цілому у зоні проведення операції.

СДуП за допомогою телескопічної розсувної труби призначена для заправки, переважно, бомбардувальників i винищувачів. На літакузаправнику (танкері) встановлюються паливні баки, насоси і жорстка телескопічна труба, на кінці якої є датчик палива. Труба кріпиться шарнірно у хвостовій частині літака-заправника і має аеродинамічне кермо, управління яким здійснює оператор, який знаходиться на борту танкера.

Для заправки за цією системою літак, що заправляється, із деяким зміщенням вниз відносно ешелону заправника бере однаковий із ним курс, чітко дотримуючись однакової швидкості. Оператор літака-заправника за допомогою наявного на трубі аеродинамічного керма направляє іiі на приймач палива літака, що заправляється, і вводить у зачеплення датчик із приймачем. Як тільки датчик входить у зачеплення із приймачем, відкри- 
вається клапан, і паливо із баків літака-заправника починає поступати у паливну систему літака, що заправляється. Як бачимо, стабільність процесу дуже висока, особливо враховуючи систему автоматики, яка використовується на всіх сучасних літаках відповідного призначення.

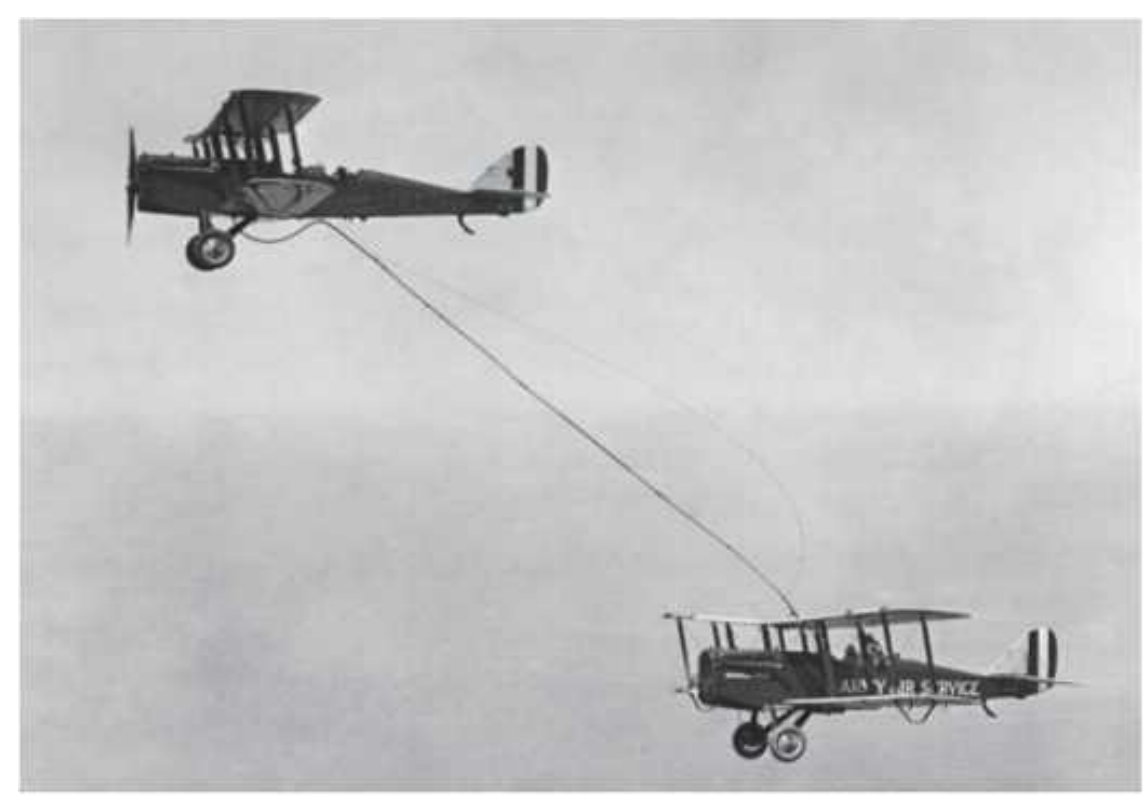

Рис. 2. Дозаправка літаків $\quad$ у $\quad$ повітрі
тросів і гнучкого шлангу $(23.06 .1923$ р.)

Телескопічна труба допускає поступальні переміщення літаків один відносно одного. Вони можливі завдяки шарнірному кріпленню труби до фюзеляжу літака-заправника і шарнірного замку зачеплення датчика із приймачем. Якщо тиск палива або механічні зусилля, що виникають під час відносних переміщеннях літаків, перевищують допустимі, датчик i приймач виходять із зачеплення, і перекачування палива припиняється.

На рис. 3 показаний процес заправки літака $F-22$ від танкера KC-10 Extender.

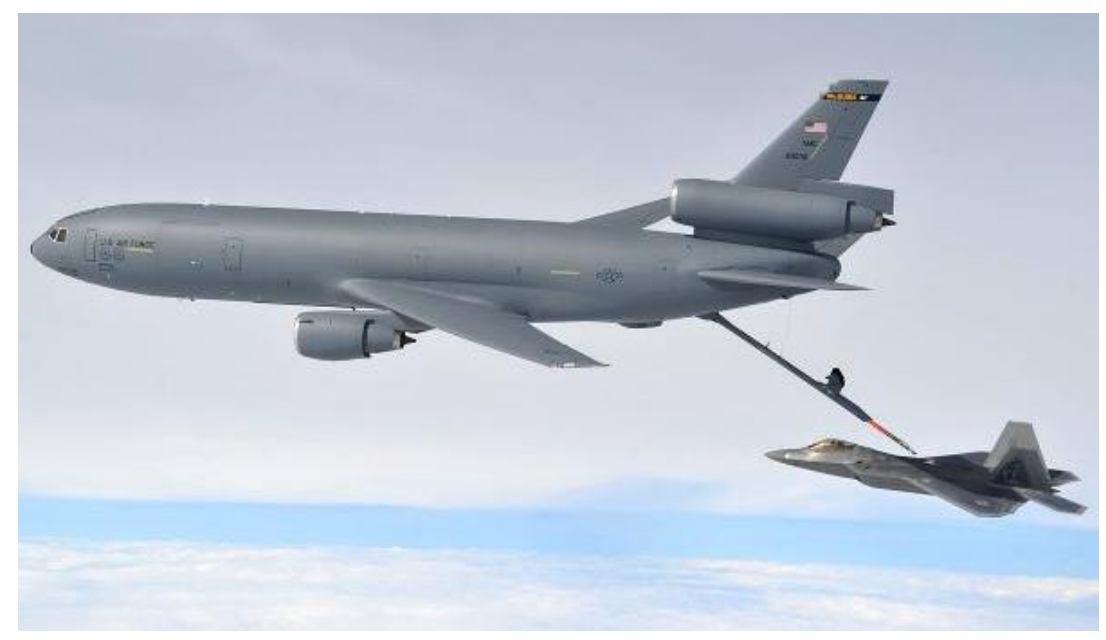

Рис. 3. Заправка літаків за допомогою телескопічної труби 
Заправка літаків паливом у повітрі за використання жорсткої труби може здійснюватися на швидкостях польоту до 500 км/год. Максимальна швидкість перекачування палива може досягати 4500 л/хв. Головний недолік подібної системи - зменшення максимально можливої висоти польоту під час заправки приблизно на 3000 - 3500 м, що висуває певні обмеження для швидкісних реактивних літаків.

До недоліків СДуП на основі жорсткої телескопічної труби можна віднести вібрацію заправної телескопічної труби, що виникає на великих швидкостях, а також пульсацію тиску палива у разі відносних переміщень літаків. Це, у свою чергу, вимагає установки спеціальних гасителів вібрацій у паливних системах. Крім того, у деяких випадках механічний зв'язок між літаком-заправником і літаком, що заправляється, може сприяти зближенню літаків і викликати небезпеку їх зіткнення або поломки жорсткої заправної труби. Також можливі випадки роз'єднання датчика із приймачем палива. Для літаків «Ан», моделі яких були вказані вище, такі обмеження, одначе, є припустимими.

У разі використання СДуП за допомогою гнучкого шланга і конуса, на літаку-заправнику встановлюються паливні баки, насоси і лебідка, за допомогою якої випускається гнучкий заправний шланг. На кінці шланга встановлений конус із датчиком палива. Літак, що заправляється, пристроюється ззаду із деяким приниженням до літака-заправника, займаючи таке положення, за якого його приймач палива може увійти до конуса випущеного заправного шланга і за допомогою замка з'єднатися із датчиком палива. Клапан відкривається, і паливо по шлангу починає подаватися на літак. Після закінчення заправки клапан закривається і літак, що заправляється, починає зменшувати швидкість, натягуючи заправний шланг. За певного натягу шланга відбувається роз'єднання приймача і датчика палива.

У порівнянні із системою заправки за допомогою жорсткої телескопічної труби, система із гнучким шлангом дозволяє швидко поповнювати запас палива навіть на великих швидкостях і не вимагає спеціального оператора заправного устаткування. Управління випуском і прибиранням заправного шланга $є$ дистанційним і може виконуватися будь-яким членом екіпажа літака-заправника. Ця система дозволяє також одночасно заправляти декілька винищувачів або інших невеликих літаків від одного літаказаправника. У останньому випадку заправне устаткування встановлюється на літаку-заправнику у фюзеляжі та у спеціальних гондолах на кінцях крила.

На рис. 4 показаний процес дозаправки у повітрі літака $A 400 M$ [3].

Скорочення часу заправки літаків може досягатися перекачуванням палива під тиском, яке створюється спеціальними насосами на літакузаправнику. У паливних системах літаків встановлюються автоматичні клапани, що перекривають доступ палива у баки після їх наповнення. Крім того, у паливних системах літаків, що заправляються, передбачаються спе- 
ціальні пристрої, які оберігають системи від гідравлічного удару, котрий виникає у разі закриття автоматичних клапанів паливних баків літака, який заправляється, або у разі порушення контакту між датчиком і приймачем. Подача палива під тиском викликає необхідність установки на літаках, що заправляються, трубопроводів збільшеного перерізу із поліпшеними ущільненнями у місцях з'єднання. Подальше вдосконалення заправки літаків у повітрі пов'язане зі збільшенням надійності устаткування.

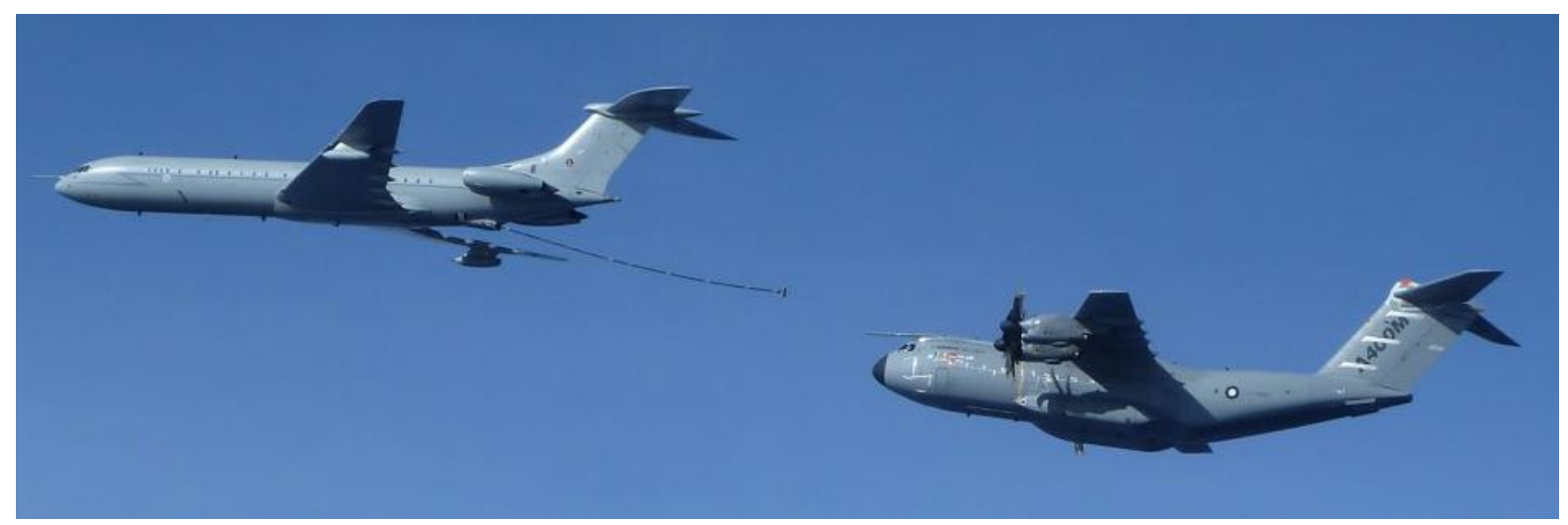

Рис. 4. Заправка у повітрі $A 400 M$ із використанням СДуП на основі гнучкого шланга і конуса

На теперішній час, майже всі процедури заправки у повітрі є автоматизованими. Автоматична СДуП дозволяє істотно скоротити час заправки, однак, не виключає із екіпажу літака-заправника оператора, який виконує нагляд за роботою системи, а також керує процесом у виникненні позаштатних ситуацій.

Першою у світі офіційно підтвердженою повністю автоматичною заправкою у повітрі вважається заправка літака $F$-16 від танкеру $A 310 M R T T$, яка відбулася у травні 2018 року (рис. 5, [4]). Найближчим часом очікуємо встановлення таких автоматичних СДуП на серійні літаки-заправники A330MRTT .

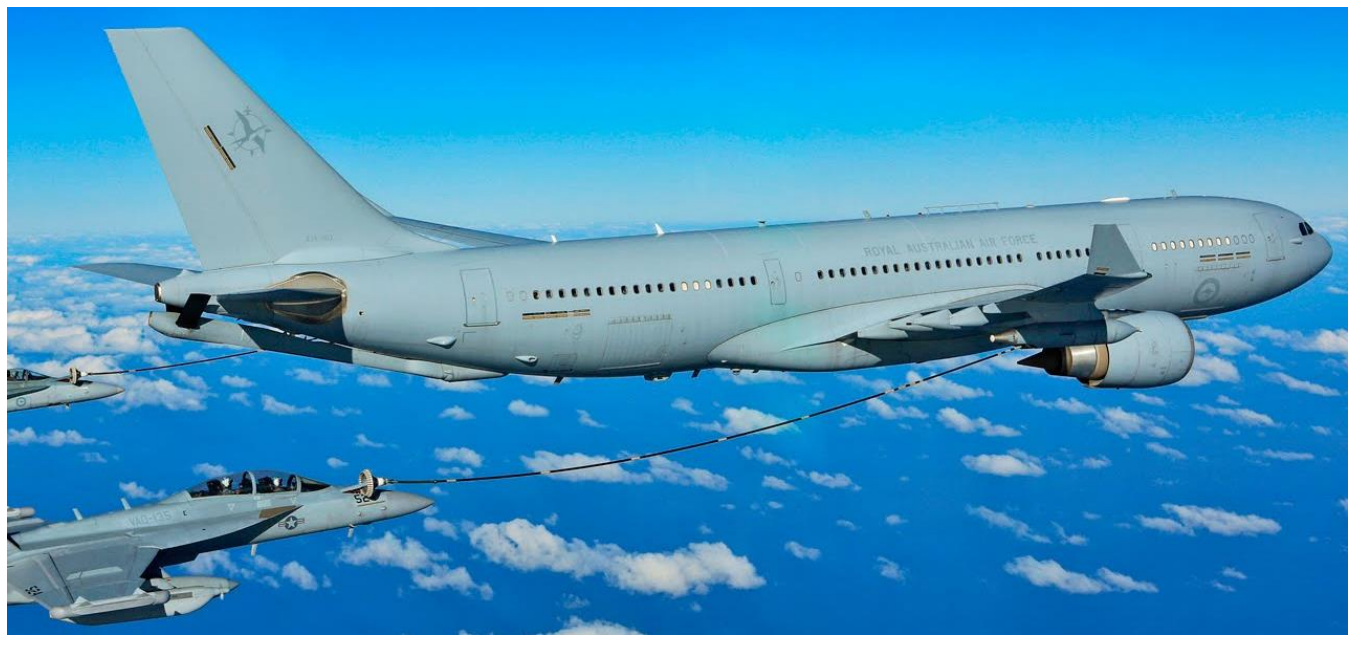

Рис. 5. Перша у світі автоматична заправка літаків у повітрі 
Розробкою систем автоматичної дозаправки у повітрі займаються і інші компанії, зокрема Northrop Grumman [5]. Компанія створює автоматичну СДуП на базі перспективних безпілотних ЛА MQ-25 Stingray, які використовують для дозаправки у повітрі інших безпілотних ЛА, а також пілотованих літаків. Крім того, вони вестимуть розвідку.

До недоліків системи заправки за допомогою гнучкого шланга і конуса слід віднести великі гідравлічні втрати, що утворюються у шлангу, під час перекачування палива, що вимагає установки на літаку-заправнику декількох насосів великої потужності. У разі зближення літака, що заправляється, із літаком-заправником відбувається деяке провисання заправного шланга, який під дією аеродинамічних сил отримує коливальні рухи, нівелювання якими відбувається за допомогою лебідки. Ще одними істотним недоліком такої СДуП є недостатня гнучкість шланга у разі низьких температур навколишнього повітря, що вимагає значних зусиль для його прибирання.

Виконавши огляд таких систем, можна зробити висновок, що найбільш доречно для літаків Ан-70, Ан-32, Ан-178 встановити систему дозаправки «Шланг-Конус».

\section{Модель встановлення адаптивної СДуП для літаків «Ан»}

Враховуючи наведені особливості різних СДуП, на військовотранспортних літаках «Ан», що експлуатуються у Збройних силах України та Національній гвардії, найбільш прийнятною системою дозаправки бачиться система із використанням гнучкого шлангу і конуса. Така СДуП повинна встановлюватися, як на літаках, що вже експлуатуються, так і на нових, що розробляються, які керівництво країни передбачає для закупівлі у відповідні авіапарки. Зауважимо, що із зрозумілих причин мова йде про ЛА виключно виробництва ДП «АНТОНОВ».

Модель передбачає встановлення відповідних елементів системи на:

- літаки, що будуть заправлятися (Ан-32, Ан-132, Ан-70, Ан-148, Ан-178);

- літаки-танкери (Ан-26, Ан-32, Ан-124 тощо).

Проведення відповідних робіт, стосовно до обох учасників заправки одночасно (літак-заправник, або танкер, та літак, що заправляється), дозволить отримати власний комплекс (або комплекси) повітряної заправки, який буде максимально адаптованим до особливостей конструкції «Анів». Так, СДуП із використанням гнучкого шлангу і конуса включає у себе цілий комплекс підсистем і компонентів, що монтуються:

- на літаку-заправнику: уніфікований підвісний агрегат заправки (УПАЗ), пристрій випуску-прибирання шланга, паливний бак, трубопроводи, засоби кріплення усередині фюзеляжу, засоби кріплення УПАЗ ззовні фюзеляжу інші агрегати; 
- на літаку, що заправляється: заправна штанга, головка приймача, трубопроводи від головки до основних (крилових) баків інші агрегати.

Крім цього, на обох ЛА-учасниках заправки встановлюються датчики положення конуса і заправної штанги, засоби визначення взаємного положення конуса і заправної штанги, котрий містить обчислювач. Головна особливість УПАЗа - його автономність. Насос, який перекачує паливо, в агрегаті має привід від турбіни, що використовує енергію потоку, що набігає. Продуктивність може досягати 2900 л/хв. і більше.

У якості аналога конуса-датчика пропонується використовувати наступну конструкцію (рис. 6).

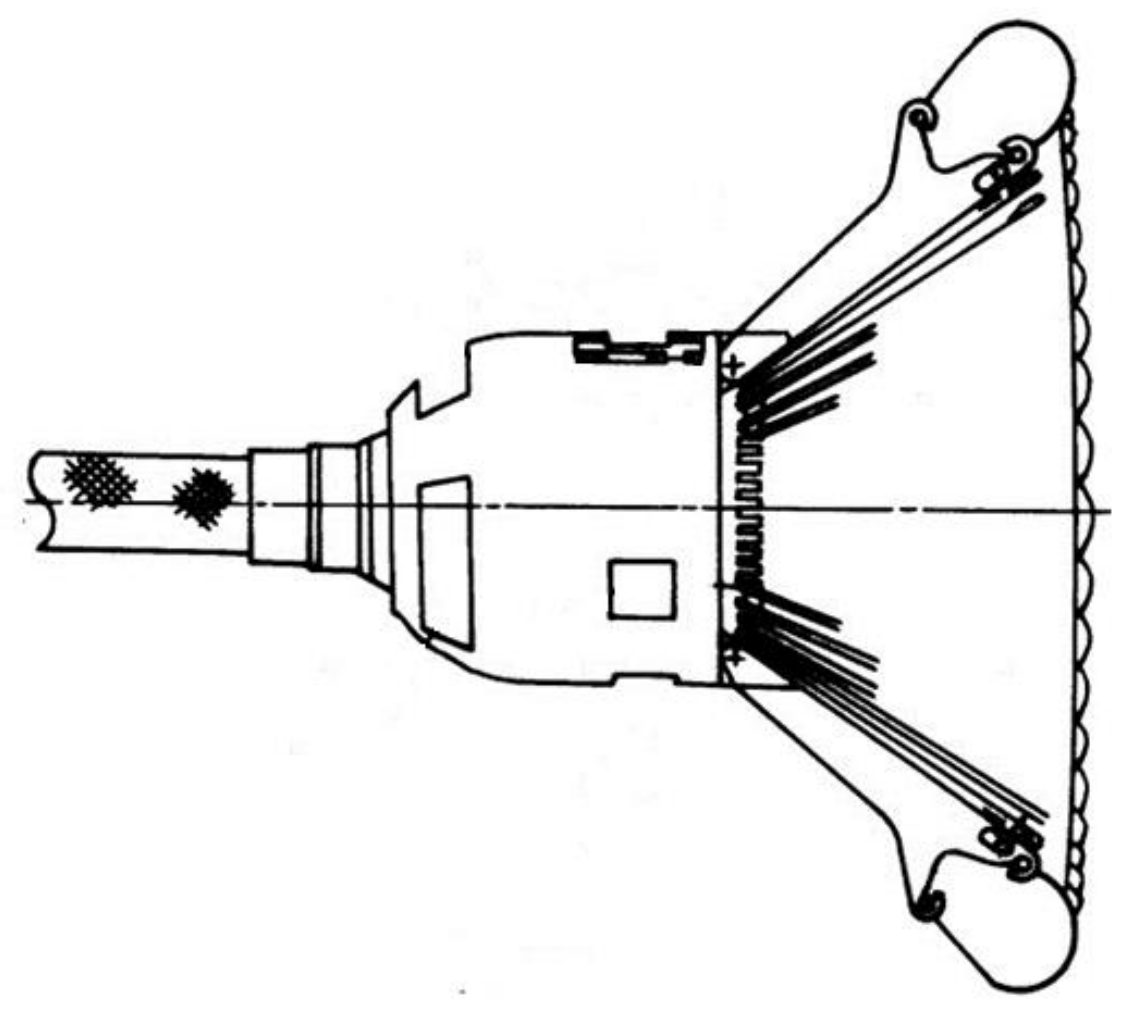

Рис. 6. Конус-датчик системи дозаправки

У конструкції приводом шлангової лебідки служить повітряна турбіна, вал якої через редуктор жорстко пов'язаний із барабаном. Конусдатчик агрегату містить корпус, кульовий шарнір, стабілізуючий аеродинамічний конус. На корпус конуса встановлений кожух, на передній стороні якого виконані три кільцеві канали. На бічних сторонах виконані три щілинних вікна, на яких встановлені три заслінки із трьома пристроями для їх переміщення, а на корпусі конуса встановлені два акселерометра у двох взаємно перпендикулярних площинах симетрії конуса.

У якості аналога приймача палива, доречно розглянути наступну конструкцію (рис. 7). 


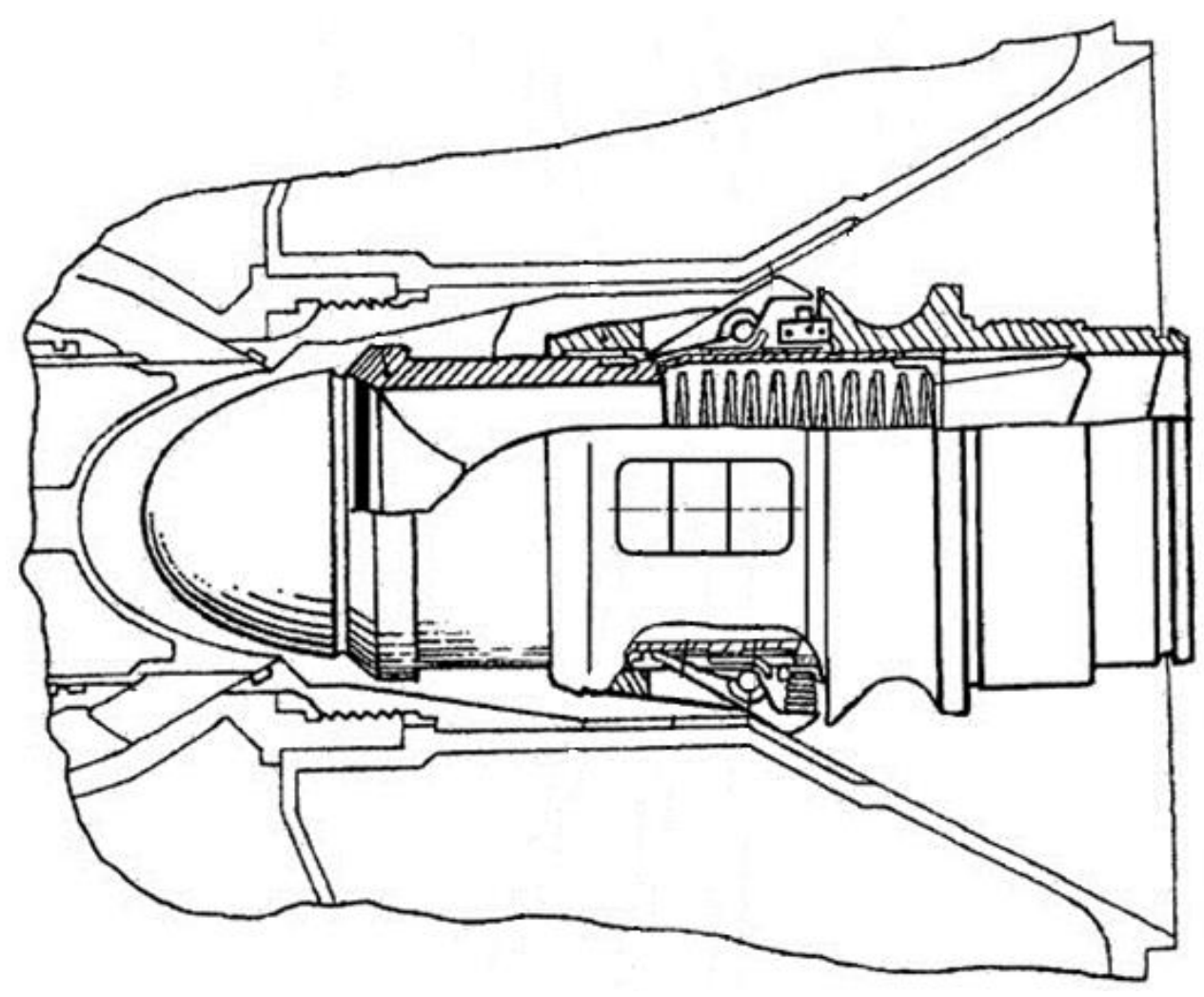

Рис. 7. Приймач палива системи дозаправки

Приймач палива містить головку, паливний клапан, фіксатор паливного клапана, систему сигналізації із штовхачем і кінцевим вимикачем. У голівці приймача палива встановлений автономний реєстратор числа контактів, що складається із п'єзоелектричного акселерометра, ємнісного накопичувача напруги і лічильника електричних імпульсів. Успішний технічний результат полягає у забезпеченні надійності вимірювання числа контактів приймача палива із конусом-датчиком.

Запропонована конструкція СДуП може розглядатися як базовий варіант для обговорення із розробником. У якості останнього, найдоречнішим варіантом є відповідні проектні підрозділи ДП «АНТОНОВ». Відсутність досвіду у виконанні таких робіт може нівелюватися відповідним фінансуванням та організацією ряду відряджень на відповідні фірми світу. Крім цього, кооперація у виробництві компонентів СДуП теж не виключається.

Стан програм виробництва літаків «Ан» в Україні наразі $є$ незадовільним. Серійна продукція не випускається, а на дві останні дослідних зразка - Ан-132 і Ан-178 - і дотепер не отримано Сертифікатів типу. Суперечлива інформація у ЗМІ та офіційна від керівництва фірми із приводу продовження виробництва одних моделей і організації виробництва інших ставить питання щодо взагалі такої можливості. 
Враховуючи вищенаведене, більш перспективним $є$ варіант модернізації існуючих у силових відомствах України літаків під заправники і тих, які можуть дозаправлятися у повітрі.

\section{Висновки}

Необхідність мати сучасні ЛА у силових відомствах і Армії України, як показали події на сході країни і у Криму, є гострою і беззаперечною. Відносно мирний стан, що зберігається на інших територіях, потребує мати літаки із достатньо високими характеристиками для підтримання цього стану. Майже повне припинення випуску так званого «кінцевого продукту», а саме літаків, у державі, яка продовжує називати себе країною «із повним замкненим циклом виробництва», є заявкою на втрату такого статуcy.

Всі ці три тези є ланками одного ланцюга, задача якого - зберігати, підтримувати і створювати авіаційну продукцію, для мирних i, на жаль, військового часів.

Наявність у авіаційних парках прогресивних країн літаків із можливістю автономної роботи без прив'язування до аеродромів базування $\epsilon$ фактом, народження якого відбулося не сьогодні. I зараз лише можливість дозаправки у повітрі є найбільш поширеним способом забезпечення такої автономності. Поява літаків із встановленою СДуП відбувається або у результаті їх виробництва як основної моделі, так і шляхом модернізації.

Для флоту військово-транспортної авіації України можливість забезпечення автономності роботи на першому етапі впровадження може стосуватися саме модернізації існуючих машин, однак, створення базових літаків із уже встановленими СДуП також розглядається як перспективний варіант. Останній не тільки дозволить мати такі літаки в армії не самим дорогим шляхом, а і забезпечити замовленнями ДП «АНТОНОВ». Державний підхід у цьому питанні зможе залучити на перших етапах гроші для налагодження серійного виробництва, якого просто нема (!), а далі виготовляти літаки в інтересах України i, у разі грамотного менеджменту, інших країн.

Запропонована модель встановлення СДуП на літаках «Ан»є базовою для подальшого обговорення із розробниками.

\section{Список використаної літератури}

1. Аваков заинтересовал турецкого коллегу украинским Ан-178 [Електронний ресурс] // Електронне джерело. - 2019. - Режим доступу до реcypcy: https://www.segodnya.ua/politics/avakov-zainteresoval-tureckogokollegu-ukrainskim-an-178-opublikovany-foto-1334260.html. 
2. МВД Украины закажет 13 новых Ан-178 [Електронний ресурс] // Електронне джерело. - 2019. - Режим доступу до ресурсу: https://delo.ua/business/mvd-ukrainy-zakazhet-13-novyh-an-178-354634/.

3. Транспортник А400М впервые дозаправился в воздухе [Електронний ресурс] // Електронне джерело. - 2013. - Режим доступу до ресурсу: https://dosug.md/ru/news/97480.

4. Дозаправка в воздухе стала автоматической [Електронний ресурс] // Електронне джерело. - 2013. - Режим доступу до ресурсу: https://www.popmech.ru/weapon/363062-dozapravka-v-vozduhe-stalaavtomaticheskoy/.

5. Беспилотный заправщик «Жалящий скат» поднялся в воздух в США [Електронний ресурс] // Електронне джерело. - 2013. - Режим доступу до ресурсу: https://topwar.ru/162664-sozdannyj-na-osnove-sekretnogoprototipa-zhaljaschij-skat-podnjalsja-v-vozduh.html. 